\title{
Lipid Peroxidation Inhibitory Activity In vitro of Mezzetia parvi- flora Becc. Wood Bark Polar extract
}

\author{
Mufidah Murdifin ${ }^{1 *}$, Ermina Pakki ${ }^{1}$, Gemini Alam ${ }^{1}$, Marianti A. Manggau², Lukman Muslimin ${ }^{3}$, M. Rusdi ${ }^{4}$, Elly Wahyudin ${ }^{2}$
}

Mufidah Murdifin, ${ }^{1 *}$ Ermina

Pakki, ${ }^{1}$ Gemini Alam, ${ }^{1}$ Marianti A.

Manggau, ${ }^{2}$ Lukman Muslimin, ${ }^{3}$

M. Rusdi, ${ }^{4}$ Elly Wahyudin ${ }^{2}$

'Department of Pharmacognosy

Phytochemistry, Faculty of Pharmacy,

Hasanuddin University, INDONESIA.

2Department of Pharmacology, Faculty

of Pharmacy, Hasanuddin University,

Makassar, INDONESIA.

3STIFA Makassar, INDONESIA.

${ }^{4}$ Department of Pharmacy, Faculty of Health, Alauddin Islamic State University Makassar, INDONESIA.

\section{Correspondence}

\section{Mufidah Murdifin}

Pharmacognosy and Phytochemistry Department, Faculty of Pharmacy, Hasanuddin University, Makassar, INDONESIA.

E-mail: mufidahmurdifin@yahoo.com, mufidahmurdifin@unhas.ac.id

\section{History}

- Submission Date: 31-10-2016;

- Review completed: 08-11-2016;

- Accepted Date: 18-11-2016.

DOI : 10.5530/pj.2017.2.28

Article Available online http://www.phcogj.com/v9/i2

\section{Copyright}

(c) 2016 Phcog.Net. This is an openaccess article distributed under the terms of the Creative Commons Attribution 4.0 International license.

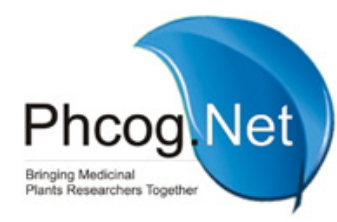

\begin{abstract}
Introduction: The wood bark of Mezzetia parviflora Becc, has long served as one of the most important traditional herbal medicine sources in Buton Regency, Southeast Sulawesi. M. parviflora extracts were rich in polyphenols. This study was aimed to explore the lipid peroxidation inhibitory activity of polar extract of $M$. parviflora. Methods: The polar extract is the result of ethanol extract partition solved in acetone. The extract will keep polar components which are insoluble in acetone. Assayed methods applied are ß-carotene bleaching inhibition, thiobarbituric acid reactive substance (TBARS) measurement, and continuous monitoring of conjugated dienes formation in LDL. Results: M. parviflora extract inhibit ß-carotene/ linoleic acid oxidation, showed by IC50 value of $15.83 \mu \mathrm{g} / \mathrm{ml}$ in 30th minute; but the potency will be reduced to IC50 value of $111.19 \mu \mathrm{g} / \mathrm{ml}$ and $225.07 \mu \mathrm{g} / \mathrm{ml}$ after the 60th and 120th minute of incubation. M. parviflora extract inhibit MDA formation as for linoleic acid peroxidation product until the third day; at 20,40,60,80 and $100 \mu \mathrm{g} / \mathrm{ml}$ inhibit MDA formation as many as 29.16 $\pm 2.41 \%, 4.24 \% \pm 43.27,54.08 \pm 2.87 \%, 59.88 \pm 1.90 \%$, and $69.75 \pm 2.32 \%$, respectively. M. parviflora extract at $50 \mathrm{\mu g} / \mathrm{ml}$ can inhibit LDL-oxidation induced by $\mathrm{CuSO} 4$, performed by LDL-oxidation lag-time elongation until 70 minutes, similar ability was performed by epigallocathecin gallate at $5 \mu \mathrm{g} / \mathrm{ml}$. Conclusions: $M$. parviflora extract expressed relatively strong protection against lipid and LDL oxidation which can serve as the scientific basis of its development as a remedy for various diseases caused by lipid peroxidation.
\end{abstract}

Key words: Conjugated diene, Low-density lipoprotein, Malondilaldehyde, Mezzetia parviflora Becc, Polyphenol.

\section{INTRODUCTION}

Free radicals, formed by some endogen metabolism reactions, can attract hydrogen atom from unsaturated lipid to begin membrane lipid peroxidation. The damage which begins by lipid peroxidation may cause cancer, cardiovascular disturb, and immunodeficiency. Our body produces molecules such as vitamin $\mathrm{E}$ and enzymes, such as SOD, catalase and peroxidase to control lipid peroxidation. Meanwhile the instability between endogen antioxidant and free radical production, may lead to "oxidative stress" and occurrence of chronic disease. ${ }^{1-6}$ To prevent that situation, antioxidant is needed where generally come from plant rich of phenolic compound. ${ }^{6-9}$

Mezzetia is an indigenous plant in Andaman, Thailand peninsula, Malaysia peninsula, Sumatra, Kalimantan and Maluku. ${ }^{10,11}$ Mezzetia consist of 4 species, one of them is Mezzetia parviflora which traditionally applied as a medicine in some diseases, such as tumor, asthma, hiper cholestrol, diabetes, and other diseases related to cell damages because of free radical activity. The previous research proof that M. parviflova scavenge DPPH free radical effectively where $\mathrm{IC}_{50}$ which is insoluble in acetone extract, ethanol extract and acetone extract respectively $21.79,30.22,60.73$, and $262.55 \mu \mathrm{g} / \mathrm{ml}$. Insoluble in acetone extract performed higher antioxidant activity level than ascorbic acid $\left(\mathrm{IC}_{50}=30.22 \mathrm{ug} / \mathrm{ml}\right)$. High percentage of antioxidant activity related to phenolic condensed tannin in acetone extract that is $26.46 \pm$ $0.315 \mathrm{mg} / \mathrm{mg}$ of the extract (calculated as quebracho tannin). ${ }^{12}$

This research conducted to evaluate lipid anti-peroxidation activity of Mezzetia parviflora Becc. Wood bark polar extract. The applied assayed methods are $\beta$-carotene bleaching inhibition, thiobarbituric acid reactive substance (TBARS) measurement, and continuous monitoring of conjugated dienes (malondialdehyde-MDA) formation in LDL. The result may become a scientific proof about $M$. parviflora extract usage in solving lipid oxidation disease such as atheroschlerosis.

\section{MATERIALS AND METHODS}

The UV-Visible spectrophotometer (Hewlett Packard) was used to measure the absorption value. $\beta$-Carotene, LDL, linoleic acid, and 1,1,3,3-tetramethoxypropane (MDA) were purchased from Sigma Aldrich; $\alpha$-tocopherol, thiobarbituric acid, trichloroacetic acid, $\mathrm{CuSO}_{4}, \mathrm{HCl}$, ethanol, and acetone were an analytical grade from E-merck.

\section{Wood bark Collection and Extraction}

Mezzetia parviflora Becc. wood bark were collected from Buton regency, Southeastern Sulawesi province and identified at Herbarium Bogoriense, Bogor. $M$. parviflora wood bark powder was extracted by eth- 
anol $70 \%$ with maceration method and the solvent was evaporated by rotary evaporator then freeze dried. Ethanol extract was partitioned by acetone, partition were finished when acetone gave no color and KLT perform visible appearance difference between soluble and insoluble acetone extract.

\section{Lipid Peroxidation Inhibitory Test}

Inhibition of lipid peroxidation based on the extract's ability to protect linoleic acid from heat-induced oxidation was assessed. Two methods were used to describe the effect of $M$. parviflora extract: the inhibition of $\beta$-carotene bleaching method and inhibition of thiobarbituric acid reactive substance (TBARS) formation.

\section{$\beta$-carotene bleaching inhibition method}

This assay conducted based on the measurement of $\beta$-carotene oxidative bleaching in $\beta$-caroten/linoleic acid mixture with and without the addition of $M$. parviflora, the method described by Kikuchi and Kitamura (1987) with a slight modification. ${ }^{13}$ Briefly, $6.0 \mathrm{mg}$ ß-carotene was dissolved in $10 \mathrm{ml}$ of chloroform, then $1 \mathrm{ml}$ of solution pipetted to glass filled of $20 \mathrm{mg}$ linoleic acid. $5 \mathrm{ml}$ of mixture then pipetted to reaction tube filled of extract in various concentration, mixed homogenously. Sample absorptions were conducted before and after incubation at $50^{\circ} \mathrm{C}$ for 30,60 , and 120 minutes. $\beta$-carotene bleaching inhibition percentage was calculated by the following formula:

$\%$ inhibition $=\left[1-\left(\mathrm{AA}_{(120)}-\mathrm{AC}_{(120)}\right) /\left(\mathrm{AC}_{(0)}-\mathrm{AC}_{(120)}\right)\right] \mathrm{X} 100$

$\mathrm{AA}_{(120)}$ : sample absorbance at $\mathrm{t}=30,60$ or 120 minute

$\mathrm{AC}_{(120)}$ : control absorbance at $\mathrm{t}=30,60$ or 120 minute

$\mathrm{AC}_{(0)}$ : control absorbance at $\mathrm{t}=0 \mathrm{~min}$

The percentage of inhibition of $\beta$-carotene bleaching produced by each concentration of extract then tabulated. The $\mathrm{IC}_{50}$ (Inhibitory Concentration $50 \%$ ) value was calculated by using probit analysis.

\section{Thiobarbituric Acid Reactive Substance (TBARS) Formation Inhibition Method}

Malondilaldehyde (MDA), the last product of linoleic acid oxidation, was measured with thiobarbituric acid reactive substance (TBARS) method. Briefly, 20-100 $\mu \mathrm{g} / \mathrm{ml}$ of $M$. parviflora extract dilution were prepared with water as a solvent. $4000 \mu \mathrm{l}$ of this solution was mixed by $1000 \mu \mathrm{l}$ of linoleic acid (13 g in $100 \mathrm{ml}$ ) incubated in shaking water bath. Extract mixture combine with $2.5 \mathrm{ml}$ thiobarbituric acid (TBA) solution which contain $0.375 \%$ thiobarbituric acid, $15 \%$ trichloroacetic acid and $0.25 \mathrm{~N} \mathrm{HCl}$. The mixture then was boiled for 10 minutes until its color was changed into pink. The mixture then centrifuged at $5000 \mathrm{~g}$ at $25^{\circ} \mathrm{C}$ for $10 \mathrm{~min}$. Supernatant absorbance measured at $532 \mathrm{~nm}$. Standard curve obtained 1,1,3,3-tetramethoxypropane (MDA) from 0 to $10 \mathrm{ppm}$ concentration and TBARS stated as mg MDA/kg sample. ${ }^{14-16}$ Measurement continued after incubating for one to five days. Lipid peroxidation inhibition percentage was calculated by the following formula:

$\%$ inhibition $=100\left[\left(\mathrm{~A}_{\text {Control }}-\mathrm{A}_{\text {sample }}\right) / \mathrm{A}_{\text {control }}\right]$

$\mathrm{A}_{\text {sample }}$ : sample absorbance

$\mathrm{A}_{\text {control }}$ : control absorbance

\section{$\mathrm{CuSO}_{4}$-induced LDL-oxidation in-vitro inhibition}

Inhibition of LDL oxidation was measured based on the prolongation of lag time of conjugated diene formation. Extract were divided into series then incubated with LDL (Sigma Aldrich) for 18 hours at $37^{\circ} \mathrm{C}$ in water bath, in plastic tube of diameter $1 \mathrm{~cm}$ by incubating the extract, LDL $\left(100 \mathrm{mg}\right.$ protein/L) and $\mathrm{CuSO}_{4}(5 \mu \mathrm{mol} / \mathrm{L})$. Diena conjugated formation monitored continously by measuring its absorption at $234 \mathrm{~nm},{ }^{17-19}$ each 10 min interval time for 360 minutes by UV-VIS spectrophotometer.

\section{RESULTS AND DISCUSSION}

\section{$\beta$-carotene bleaching inhibition method}

$\beta$-carotene bleaching inhibition method was measured based on the ability of an antioxidant to inhibit orange color reduction of $\beta$-carotene due to the oxidation occurred in linoleic acid/ $\beta$-carotene mixture. ${ }^{13,20-22}$ $\beta$-carotene is very sensitive to free radical formed by linoleic acid oxidation. Linoleic acid free radical formed when boiled will attract hydrogen atom of methylene diallylic, then formed peroxide fee radical forces conjugated double bond of $\beta$-carotene which is responsible for its carotenoid orange color which span at 400-500 nm.

The result indicates that $M$. parviflora extract inhibited $\beta$-carotene/linoleic acid oxidation and progressive activity occurring along with extract concentration. But, this activity was weaker than Vitamin $\mathrm{E}$ activity. $\mathrm{IC}_{50}$ value $(15.83 \mu \mathrm{g} / \mathrm{ml})$ indicated that the extract inhibited linoleic acid oxidation in 30 minutes. The value was two times weaker than vi$\operatorname{tamin} \mathrm{E}(6.77 \mu \mathrm{g} / \mathrm{ml})$. The extract potency at the $60^{\text {th }}-120^{\text {th }}$ minute was sharply decrease i.e. 19 times $(111.19 \mu \mathrm{g} / \mathrm{ml})$ and 25 times $(225.07 \mu \mathrm{g} /$ $\mathrm{ml}$ ) as weak as vitamin $\mathrm{E}$ (Table 1 ). The difference of extract polarity and $\beta$-carotene is the reason of that phenomenon. Recent studies reported that lower polarity of vitamin $\mathrm{E}$ result in better dissolution in lipid phase and more efficient in protecting linoleic acid. ${ }^{23,24}$

Table 1: Inhibition of $\beta$-carotene bleaching by $M$. parviflora extract compared to Vitamin E

\begin{tabular}{cccc}
\hline \multirow{2}{*}{ Sample } & \multicolumn{2}{c}{ Inhibition of beta-carotene bleaching (\%) } \\
\cline { 2 - 4 } & $30 \mathrm{~min}$ & $60 \mathrm{~min}$ & $120 \mathrm{~min}$ \\
\hline M. parviflora extract & & & \\
$100 \mu \mathrm{g} / \mathrm{ml}$ & $65.10 \pm 1.02$ & $47.29 \pm 1.65$ & $35.01 \pm 6.27$ \\
$80 \mu \mathrm{g} / \mathrm{ml}$ & $61.59 \pm 5.49$ & $38.29 \pm 2.36$ & $34.46 \pm 3.13$ \\
$60 \mu \mathrm{g} / \mathrm{ml}$ & $59.49 \pm 5.27$ & $31.27 \pm 3.93$ & $29.91 \pm 4.31$ \\
$40 \mu \mathrm{g} / \mathrm{ml}$ & $57.77 \pm 4.30$ & $18.94 \pm 3.42$ & $22.33 \pm 4.58$ \\
Vitamin E & & & \\
$10 \mu \mathrm{g} / \mathrm{ml}$ & $86.01 \pm 3.29$ & $74.79 \pm 1.20$ & $59.72 \pm 3.17$ \\
$8 \mu \mathrm{g} / \mathrm{ml}$ & $70.112 .00 \pm$ & $64.21 \pm 4.22$ & $42.36 \pm 4.87$ \\
$6 \mu \mathrm{g} / \mathrm{ml}$ & $36.77 \pm 4.66$ & $48.86 \pm 3.95$ & $19.49 \pm 9.15$ \\
$4 \mu \mathrm{g} / \mathrm{ml}$ & $29.32 \pm 5.50$ & $35.05 \pm 2.88$ & $5.09 \pm 0.27$ \\
\hline
\end{tabular}




\section{Anti-Lipid-Peroxidation with Thiobarbituric Acid Reactive Substance (TBARS) Method}

The principle of this method is the reaction of one molecule of malondil aldehyde (MDA) and two molecules of TBA to form malonaldehydeTBA complex. There will be change into red in color and the fluorescence will be absorbed at about $500 \mathrm{~nm}$ using visible spectrophotometer. ${ }^{24}$

The graph below showed the ability of $M$. parviflora extract inhibiting linoleic acid peroxidation reaction within a period of 5 days compared to the blank.

Percentage of lipid peroxidation of linoleic acid at the third day performed that $M$. parviflora extract at the concentration of $20,40,60,80$ and $100 \mu \mathrm{g} / \mathrm{ml}$ indicated inhibition $29.16 \pm 2.41 \%, 43.27 \pm 4.24 \%, 54.08$ $\pm 2.87 \%, 59.88 \pm 1.90 \%$, and $69.75 \pm 2.32 \%$ respectively. The antioxidant activity, however, declines rapidly on the fourth day, indicated by a sharp increase in absorbance MDA after 3 days (Figure 1).

Antioxidant compound in the extract bond to free radicals formed in initial reaction, furthermore it can inhibit continuous reaction between free radical oxygen which produce reactive radical peroxide. Antioxidant neutralize radical peroxide by releasing hydrogen atom then stabilizing the radical substance during oxidation. ${ }^{25}$

\section{$\mathrm{CuSO}_{4}$-induced LDL-oxidation inhibition}

Not only linoleic acid peroxidation method but also lipid anti-peroxidation assay was conducted directly to cholestrol-LDL, because LDL oxidizes together with another oxidized lipid contribute to ateroschlerosis patophisiology through various mechanisms; include proinflamatory, imunogenic and cytotoxic. ${ }^{26,27}$

Activity assay of LDL-oxidation inhibition in this study conducted by observing the LDL-oxidation kinetic that is monitoring conjugated diena formation continously after LDL-oxidation induction by $\mathrm{CuSO}_{4}$. LDL-oxidation kinetic pictures three phases of oxidation, namely, lag phase, propagation phase and decomposition phase. Lag phase is an initial phase that is interval phase between $\mathrm{CuSO}_{4}$ addition and a quick LDL-lipid oxidation process. Initial addition of $\mathrm{CuSO}_{4}$ lipid oxidation reaction occurs slowly because antioxidant activity will protect lipid from free radical attack. Meanwhile, at the end of lag phase, the antioxidant decrease the lipid peroxidation product increase which indicated by significant increasing absorbance of conjugated diena at propagation phase. However, at decomposition phase, absorbance decrease slowly because diena conduct continuous lipid peroxidation reaction. Lag phase will be reached by determining intercept of lag phase and propagation phase. ${ }^{28}$ This is the graphic related to time (minute) and absorbance of conjugated diena at $234 \mathrm{~nm}$ after LDL-oxidation induced by $\mathrm{CuSO}_{4}$ :

Figure 2 indicates that oxidation in non-addition of antioxidant (blank) occur faster, can be seen from lag time occur at the $20^{\text {th }}$ minute. Addition of $M$. parviflora extract $50 \mu \mathrm{g} / \mathrm{ml}$ and epigallocatekhin gallat (EGCG) 5 $\mu \mathrm{g} / \mathrm{ml}$ perform the ability to inhibit oxidation velocity showed by $70 \mathrm{~min}$ lag time. Even though $M$. parviflora extract and EGCG indicate similar LDL-oxidation lag time but absorbance of EGCG is higher than M. parviflora extract. It means that conjugated diena formed at the treatments and EGCG are higher than extract formed.

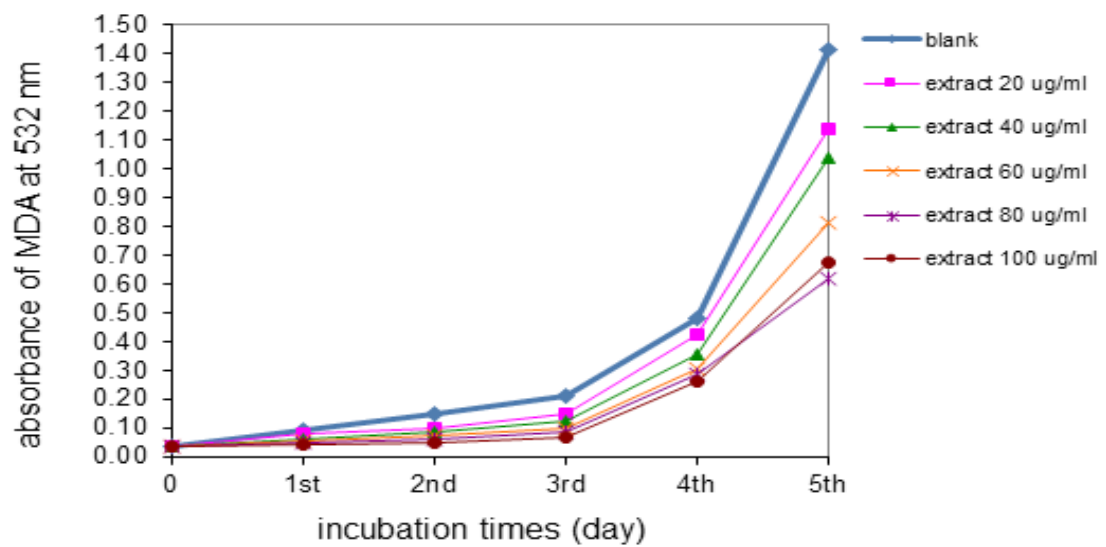

Figure 1: M. parviflora Extract Activity against linoleic acid peroxidation reactions During Interval Time 5 Days Using TBARS Method. The end product of linoleic acid oxidation was measured as MDA.

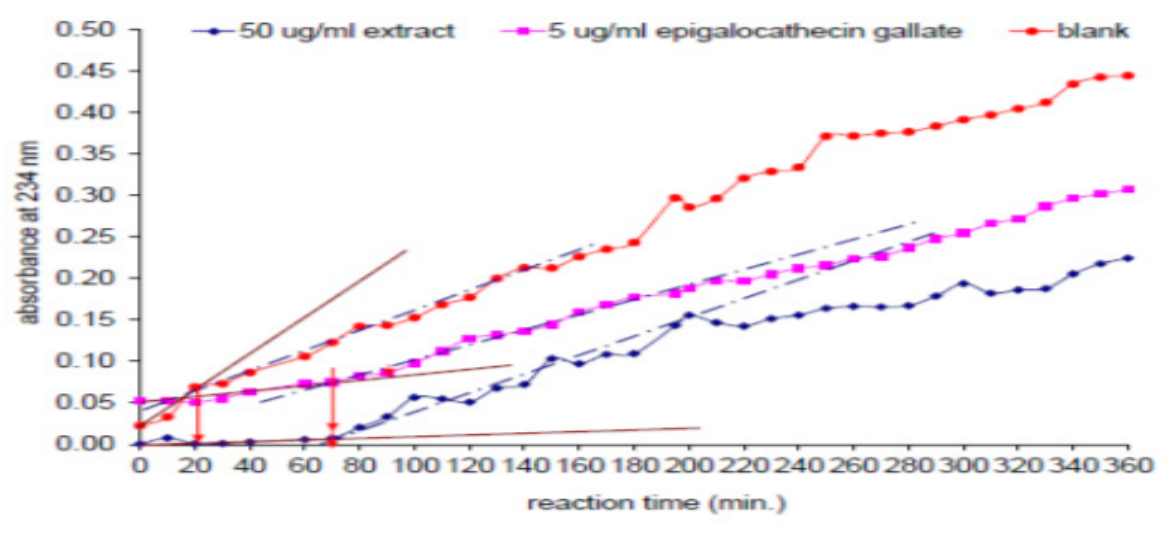

Prolongation of LDL-oxidation Lag Time

Figure 2: LDL-oxidation profile measured as conjugated diena with or without the addition of M. parviflora extract and epigalocathecin gallate. 
Normally, LDL receptor recognize specific domain with positive charge among lysine residues, arginine and histidin at apo B. But, aldehyde interaction with amino group at apoB-100 make LDL have more negative charge then its affinity to LDL receptor decrease conversely will increase the affinity of scavenger receptor ${ }^{3}$ that LDL susceptible to be caught by macrophage produce foam cell. ${ }^{29}$ Foam cell accumulation develops into atherosclerosis lesion. Oxidized-LDL together with other oxidize lipid products contribute to atherosclerosis pathophysiology through certain mechanisms include pro-inflammatory characteristic, immunogenic or cytotoxic. $^{30}$

Polyphenol prevent atherosclerosis through its mechanism in inhibiting LDL-oxidation, blocking lipid peroxidation and catching oxygen free radicals. The study of Sanches-Moreno et al. (2000) indicates that polyphenols are condensed tannins (tannin acid), flavonols (catechin, quercetin, rutin), cinnamic acids (caffeic and ferulic acid), stilbenes (resveratrol), benzoic acids (gallic acid), anthocyanidins (malvidin) are more able to inhibit oxidize LDL than Vitamin C and vitamin E. ${ }^{17}$ Parameter applied by Sanches-Moreno is CLT $_{50}$ that is a concentration which cause Lag time elongation of oxidize LDL as many $50 \%$ as the blank. Benzie dan Szeto (1999) stated that cathecin in tea inhibit LDL oxidation invitro and in-vivo based on the respective potency as follows: epigalocatechin (EGC) < epicatechin (EC) < epicatechin galat (ECG) < epigalotechin error (EGCG).$^{31}$ Another group compounds such as sterol ergostarol isolated from Pleurotus ostreatus fungi can inhibit lipid peroxidation. ${ }^{32}$ The ability to inhibit lipid peroxidation associated with anticancer activity, ${ }^{1,6}$ atherosclerosis, ${ }^{3-5}$ antiinflammation, ${ }^{33}$ and immunostimulant. ${ }^{2}$ Furthermore, the ability of $M$. parviflora extract to inhibit lipid peroxidation is an important mechanism which contributes to defense ability against various diseases caused by this process.

\section{CONCLUSIONS}

Based on the research, concluded that M. parviflora extract at 20 to 100 $\mu \mathrm{g} / \mathrm{ml}$ can inhibit lipid peroxidation reactions, both on the $\beta$-carotene bleaching test and the TBARS method. The extract $50 \mu \mathrm{g} / \mathrm{ml}$ can inhibit LDL-oxidation showing the lag-time lengthening of LDL-oxidation from $20 \mathrm{~min}$ to $70 \mathrm{~min}$, the same activity was shown by epigallocatechin gallate $5 \mathrm{ug} / \mathrm{ml}$.

\section{ACKNOWLEDGEMENT}

The study was supported by The Department of National Education of Republic of Indonesia for the Research Grants.

\section{CONFLICT OF INTEREST}

All co-authors have seen and agree with the contents of the manuscript and there is no financial interest to report. We certify that the submission is original work and is not under review at any other publication.

\section{ABBREVIATION USED}

$\mathrm{IC}_{50}$ : inhibition concentration 50\%; LDL: low density lipoprotein; MDA: malondilaldehyde; TBARS: thiobarbituric acid reactive substance; UVVIS: ultra violet - visible.

\section{REFERENCES}

1. Zhong $H$, Yin $H$. Role of lipid peroxidation derived 4-hydroxynonenal (4-HNE) in cancer: Focusing on mitochondria. Redox Biology. 2015;4:193-9. Available from: https://www.ncbi.nlm.nih.gov/pmc/articles/PMC4803793/.

2. Dingjan I, Verboogen DRJ, Paardekooper LM, Revelo NH, Sittig SP, Visser LJ, et al. Lipid peroxidation causes endosomal antigen release for cross-presentation. Scientific Reports 6, Article number: 22064 (2016). Publications at Bielefeld University. Available from: https://pub.uni-bielefeld.de/publication/2901574.

3. Young IS, McEneny J. Lipoprotein Oxidation and Atherosclerosis. Biochemica Society Transactions. 2001;29(2):358-62. Available from: http://www.biochems- octrans.org/content/29/2/358.full-text.pdf.

4. Stocker R, Keaney JF. Role of Oxidative Modifications in Atherosclerosis. Physiol Rev. 2004;84(4):1381-478. Available from: http://physrev.physiology.org/content/84/4/1381.long

5. Libby $P$, Ridker PM, Maseri A. Inflammation and atherosclerosis. Circulation. 2002;105(9):1135-43. Available from: http://circ.ahajournals.org/content/105/9/1135

6. Jang M, Cai L, Udeani GO, Slowing KV, Thomas CF, Beecher CWW, et al. Cancer chemopreventive activity of resveratrol, a natural product derived from grapes. Science. 1997;275(5297):218-20. Available from: http://science.sciencemag. org/content/275/5297/218.long

7. Mangiapane H, Thomson J, Salter A, Brown S, Bell GD, White DA. The inhibition of the oxidation of low density lipoprotein by (1)-catechin, a naturally occurring flavonoid, Biochem Pharmacol. 1992;43(3):445-50. Available from: https://www. ncbi.nlm.nih.gov/pubmed/1540202.

8. Hanson BA. Understanding Medicinal Plants. Their Chemistry and Therapeutic Action. Binghamton: The Haworth Press Inc.; 2005.

9. Haraguchi H. Antioxidative Plant Constituents. In: Tringali $\mathrm{C}$, Editor. Bioactive Compounds from Natural Sources. London and New York :Taylor \& Francis; 200

10. Sosef MSM, Hong LT, Prawirohatmodjo S, Editors. Prosea (Plant Resources of South East Asia) No. 5 (3):Timber Tree: Lesser Known Timber. Prosea Foundation. Bogor. Indonesia. 1998.

11. Wills JC. (revd. Airy Shaw HK) A Dictionary of the Flowering Plants and Ferns, 8th Ed. UK: Cambridge University Press; 1973.

12. Murdifin M, Wahyudin E, Lawrence GS, Subehan, Manggau MA, Alam G. Phytochemical analysis and antioxidant activity of Mezzetia parviflora Becc. Woodbark extract. Pharmacognosy Journal. 2012;4(34):18-21. Available from: http:// phcogfirst.com/article/215.

13. Kikuchi A, Kitamura K. Simple and Rapid Carotene Bleaching Tests for the Detection of Lipoxygenase Isozymes in Soybean Seeds. Japan J Breed. 1987;37(1):10-16.

14. Maqsood S, Benjakul S, Balange AK. Effect of tannic acid and kiam wood extract on lipid oxidation and textural properties of fish emulsion sausages during refrigerated storage. Food Chemistry. 2012;130(2):408-16. Available from: http://www.sciencedirect.com/science/article/pii/S0308814611010260.

15. Cetkovic GS, Canadanovic-Brunet JM, Djilas SM, Tumbas VT, Markov SL, Cvetkovic DD. Antioxidant Potential, Lipid Peroxidation Inhibition and Antimicrobial Activities of Satureja montana L. subsp. kitaibelii Extracts. Int J Mol Sci. 2007;8(10):1013-27. Available from: http://www.mdpi.com/1422-0067/8/10/1013.

16. Gavino VC, Miller JS, Ikharebha SO, Milo GE, Cornwell DG. Effect of polyunsaturated fatty acids and antioxidants on lipid peroxidation in tissue cultures. Journal of Lipid Research. 1981;22(5):763-69. Available from: https://www.ncbi.nlm.nih. gov/pubmed/7288284.

17. Sanches-Moreno C, Jimenez-Escrig A, Saura-Calixto F. Study of low-density lipoprotein oxidizability indexes to measure the antioxidant activity of polyphenols. Nutrition research. 2000;20(7):941-53. Available from: http://www.nrjournal.com/article/S0271-5317(00)00185-8/abstract.

18. Roland A, Patterson RA, Leake DS. Measurement of copper-binding sites on low density lipoprotein. Arteriosclerosis, Thrombosis and Vascular Biology. $2001 ; 21: 594-602$. Available from: http://dx.doi.org/10.1161/01.ATV.21.4.594.

19. Thuong PT, MinKyun N, Nguyen DS, Rack SS, Young ML, Dai ES, et al. Inhibitory Effect of Coumarins from Wigela subsessilis on Low density Lipoprotein Oxidation. Biol Pharm Bull. 2005;28(6):1095-97. Available from: https://www.jstage. jst.go.jp/article/bpb/28/6/28_6_1095/_article.

20. Mikami I, Yamaguchi M, Shinmoto $H$, Tsushida T. Development and Validation of a Microplate-based ß-carotene Bleaching Assay and Comparison of Antioxidant Activity (AOA) in Several Crops Measured by ß-carotene Bleaching, DPPH and ORAC Assays. Food Science and Technology Research. 2009;15:171-8. Available from: https://www.jstage.jst.go.jp/article/fstr/15/2/15_2_171/_article.

21. Kulisic T, Radonic $A$, Katalinic $V$, Milos $M$. Use of different methods for testing antioxidative activity of oregano essential oil. Food Chemistry. 2004;85(4):63340. Available from: http://www.sciencedirect.com/science/article/pii/ S0308814603003741.

22. Wang J, Liu H, Zhao J, Gao H, Zhou L, Liu Z, et al. Antimicrobial and Antioxidant Activities of The Root Bark Essential Oil of Periploca sepium and Its Main Component 2-Hydroxy-4-methoxybenzaldehyde. Molecules. 2010;15(8):580717. Available from: http://www.mdpi.com/1420-3049/15/8/5807.

23. Fukumoto LR, Mazza G. Assessing antioxidant and pro-oxidant activities of phenolic compounds. J Agric Food Chem. 2000;48(8):3597-604. Available from: http://pubs.acs.org/doi/full/10.1021/jf000220W.

24. Apak R, Guclu K, Demirata B, Ozyurek M, Celik SE, Bektasoglu B, et al. Comparative Evaluation of Various Total Antioxidant Capacity Assays Applied to Phenolic Compounds with the CUPRAC Assay. Molecules. 2007;12(7):1496-547. Available from: http://www.mdpi.com/1420-3049/12/7/1496.

25. Othman A, Ismail A, Abdul Ghani N, Adenan I. Antioxidant Capacity and Phenolic Content of Cocoa Beans. Journal of Food Chemistry. 2007;100(4):152330. Available from: http://www.sciencedirect.com/science/article/pii/ S0308814605011064.

26. Li D Mehta JL. Oxidized LDL, a critical factor in atherogenesis. Cardiovascular 
Research. 2005;68(3):353-4. Available from: http://cardiovascres.oxfordjournals. org/content/68/3/353.

27. Libby P. Inflammation in atherosclerosis. Nature. 2002;420:868-74. Available from: http://www.nature.com/nature/journal/v420/n6917/full/nature01323.html.

28. Esterbauer $H$, Jurgens $G$. Mechanistic and genetic aspects of susceptibility of LDL to oxidation. Curr Opin Lipidol. 1993:4(2):114-24. Available from: http:// journals. Iww.com/colipidology/pages/articleviewer.aspx?year=1993\&issue =04 000\&article $=00007 \&$ type $=$ abstract.

29. Stocker R Keaney JF. Role of Oxidative Modifications in Atherosclerosis. Physiol Rev. 2004;84(4):1381-478. Available from: http://physrev.physiology.org/content/84/4/1381.

30. Libby P, Ridker PM, Maseri A. Inflammation and atherosclerosis. Circula- tion. 2002;105:1135-43. Available from: http://circ.ahajournals.org/content/105/9/1135

31. Benzie IFF, Szeto YT. Total Antioxidant Capacity of Teas by the Ferric Reducing/Antioxidant Power Assay J. Agric. Food Chem. 1999;47(2):633-6. Available from: http://pubs.acs.org/doi/full/10.1021/jf9807768.

32. Dissanayake DP, Abeytunga DTU, Vasudewa NS, Ratnasooriya WD. Inhibition of lipid peroxidation by extracts of Pleurotus ostreatus. Pharmagognosy Magazine. 2009; 5(19). Available from http://www.phcog.com/text. asp?2009/5/19/266/58172

33. Tantary S, Masood A, Bhat AH, Dar KB, Zargar MA, Ganie SA. In vitro Antioxidant and RBC membrane Stabilization Activity of Euphorbia wallichii. Free Radicals and Antioxidants. 2017;7(1):13-22. Available from http://www.antiox. org/article/53

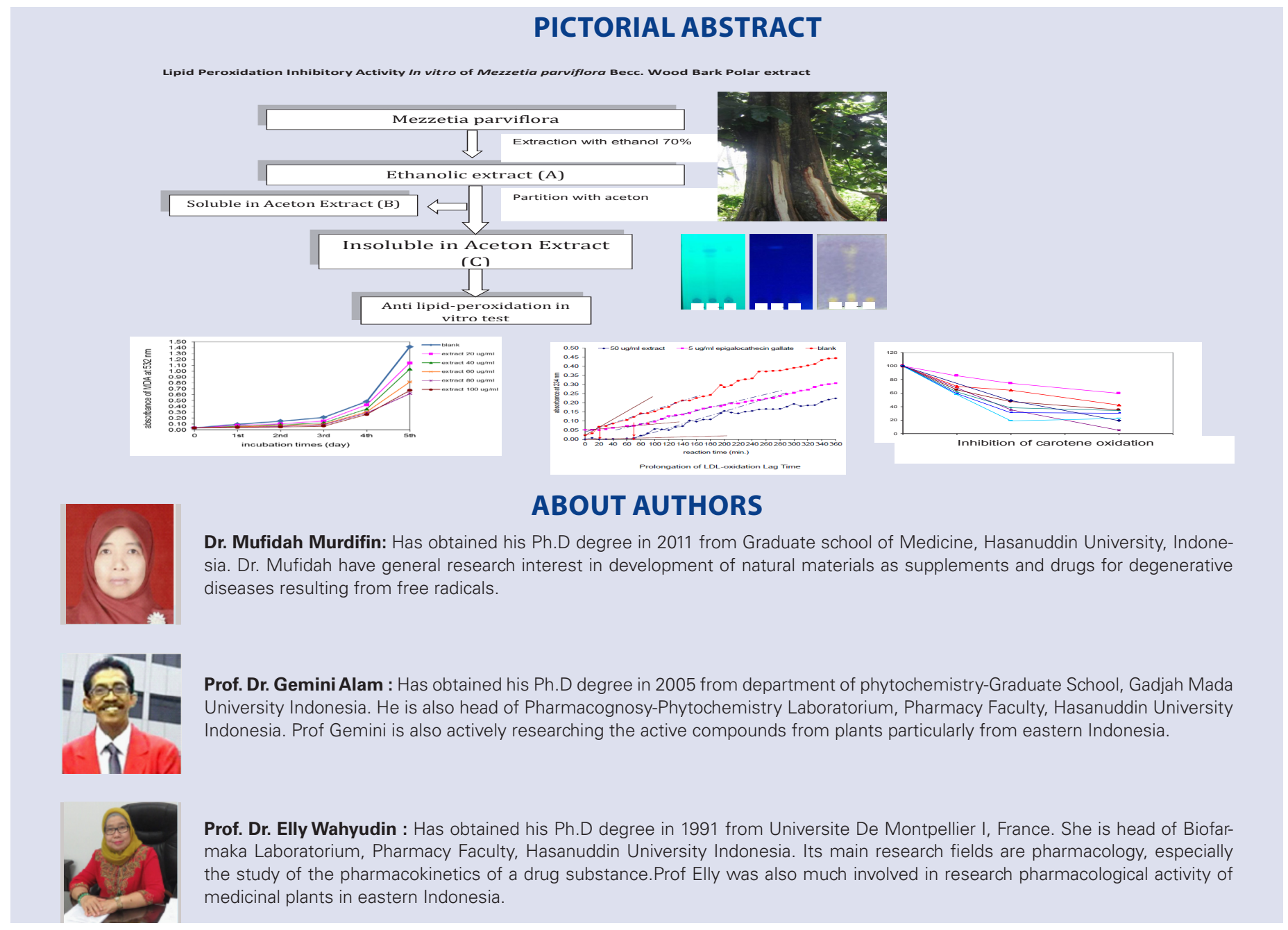

Cite this Article: Murdifin M,Pakki E, Alam G, Manggau MA, Muslimin L, Rusdi M, Wahyudin E. Lipid Peroxidation Inhibitory Activity In vitro of Mezzetia parviflora Becc. Wood Bark Polar extract. Pharmacogn J. 2017;9(2):171-5. 